\title{
Political crime and corruption take center stage: introductory notes
}

\author{
Mary Dodge ${ }^{1}\left[\right.$. Henry N. Pontell ${ }^{2}$
}

Accepted: 28 February 2021 / Published online: 17 March 2021

(c) The Author(s), under exclusive licence to Springer Nature B.V. 2021

The incidence of political crime, both known and unknown, is likely to exceed even the most unhinged estimates of what actually occurs in the elite world of whitecollar criminality. In short, data on the exact number of crimes and unethical acts committed globally by politicians and corporations are unattainable. This problem exists due to the structurally veiled nature of political criminal behavior more generally. White-collar crime conducted by high-level officials often is hidden from public view, though, as one article documents in this issue, offenders may now more openly commit unspeakable acts that become normalized, by airing dirty laundry and situating crimes in the public domain as acceptable or inevitable. This special issue offers current perspectives on political corruption that represent singularly distinct but overlapping research and commentary on the insidious and global nature of white-collar crime.

Definitions of what political crime entails are controversial, which can make it difficult to pinpoint what happened, who was responsible, and why it occurred. Offenders and offenses present a wide array of wrongdoing and opportunities for analysis. Hence, white-collar crime researchers face perplexing issues when dealing with the complexities relating to both definitions and data access. These obstacles need to be overcome in order to provide better understandings of political corruption and the necessary means to combat it.

Political crime easily fits within the parameters of white-collar crime, though some offenses against the state may represent outliers. For example, in one major analysis Ross (2003:2) emphasized that there remained "considerable confusion about what constitutes a political offense." Conceptual issues in white-collar crime, as noted by scholars Shover and Wright [12], result in skirmishes over offender/ offense distinctions and definitions that may make even the most experienced

Mary Dodge

Mary.dodge@ucdenver.edu

Henry N. Pontell

pontell@uci.edu

1 University of Colorado Denver, Campus Box 142, P.O Box 173364, Denver, CO 802017, USA

2 John Jay College of Criminal Justice, New York, NY 10019, USA 
researchers squeamish. Political offenses include crimes against the state (e.g., insurrection, terrorism, sedition) and by the state (i.e., illegal or unethical acts by political figures). More common forms include bribery, ethical misconduct, election manipulations, graft, nepotism, looting, and misuse of financial resources. Political offending can also include war crimes, genocide and ethnic cleansing, espionage, assassinations, illegal experiments, terrorism, human rights violations, money laundering, theft, and wrongful incarceration [2, 7, 9]. In this issue, Joel Martinsson notes that discovering an "all-encompassing corruption definition would for corruption researchers be like finding the Holy Grail."

Definitions of political crime are considered "broad and ill defined" and accusations of corruption can be all-encompassing and relatively common [1]: 201,[8]. Many scholars have adopted a state crime approach, though they readily concede that expansion of this term results in a definition that might include any "undesirable activities," which, according to Sharkansky [11] represents an "intellectual transgression." Friedrichs [5] also acknowledged the confusion surrounding state and governmental crimes with the latter representing a wide-range of misdeeds committed in a governmental context, often by an individual, and dependent on occupational status. The former, as defined by Friedrichs, represents actions carried out by the state itself. Geis and Meier [6] propose a rather straightforward definition of political crime that fits well-within traditional notions of white-collar criminality more generally,illegal actions committed by political officeholders in the course of their duties. An exhaustive exploration of definitional issues of political crime is beyond the scope of this introduction, but it can be emphasized that the concept continues to defy clear demarcations, and purposed definitions may result in a quagmire of incongruous offenses that are difficult to sort out accordingly.

Global jurisdictional issues, cover-ups, financial complexities, legal technicalities, political structures, and economic considerations also make attempts to research political crime difficult. The generally hidden nature of political crime involves acts by ruling elites that are clearly corrupt, yet fully ingrained in existing societal arrangements that act to thwart enforcement efforts, regulatory action, and judicial involvement. Most recently, the normalization of political malfeasance has resulted from the repeated "look at me" attitude and displays of Donald Trump as U.S. president.

Public complacency has developed from the number of overt illegal and immoral acts that are ignored, accepted, or unpunished. In this issue, Pontell, Tillman, and Ghazi-Tehrani offer a new perspective on the criminal debacle of Donald Trump's presidency. The authors frame the newest "gate" as reminiscent of a publicly-aired Watergate scandal, and examine how the alleged offenses are flagrant acts enabled by the proliferation of a new lexicon of "fake news," "cancel culture," "cult of the personality," "whataboutism," and "not me" that assisted in rationalizing wrongdoing. Pontell, Tillman and Ghazi-Tehrani explore the Trump administration's maneuvers to neutralize illegal and unethical acts in a public forum, making significant segments of the population more accepting of a wide range of political crimes. They also consider these moves as part of a larger existential war against white-collar 
and corporate crime in the United States, that not only sought to reduce regulatory capacity and enforcement efforts, but to normalize such offending itself.

Corruption in government is often explored using indices such as the World Bank's Control of Corruption, and Transparency International's Corruption Perception, and Global Integrity, which allow for quantitative comparisons across countries. Transparency International, established in mid-1990s, compiles information on corruption scandals involving "bribes and money laundering of epic proportions" (see Table 1). While particular cases are anecdotal, overall the criminal enterprises note the need for additional prosecution and preventive policies.

In many cases, political figures who reap the benefits of their ill-gotten gains have seized opportunities afforded to them by positions that feed their greed and inhumanity. In Peru, former president Alberto Fujimori, maintained a high public approval rating, despite bribing politicians and judges, employing death squads to kill guerillas, and embezzling at least US\$600 million. Similarly, Ramzen Kadyrov, the head of Chechnya, used public funds to throw birthday parties and buy a US \$2-million-dollar private boxing session with former world heavyweight boxing champion, Mike Tyson. While living in a palace with his pet tiger, Kadyrov ordered the killing of numerous rivals and committed a host of human rights violations [13].

Perhaps the most heinous political crimes documented by Transparency International are those involving collusion between governmental officials and companies [14]. Siemens Corporation, a German company, provoked a worldwide scandal by engaging in a bribery scheme with government officials and civil servants that involved approximately US\$1.4 billion.

The extensive networks of political crime immersed in alliance with legitimate businesses is sometimes discovered only after a massive depletion of private and public funds. Research studies that focus on specific aspects of political crime continue to add impressive perspectives and endeavors to expand the extant literature. In this issue, Fiona Chan, Carole Gibbs, Rachel Boratto, and Mark Speers offer an innovative examination of transnational corporate bribery. The authors acknowledge the importance of employing a white-collar crime framework to research corruption and corporate bribery. Chan and colleagues' work utilizes violation data of the Foreign Corrupt Practices Act from the US Department of Justice's Fraud Section. The article offers a valuable and insightful analysis that establishes a theoretical and practical framework for exploring and researching corporate bribery.

Political crime is highly problematic in that the extent and nature of offenses act to destroy public trust and create feelings of helplessness in the populace. Indeed, identified corruption by a political leader may result in outrage and protests but the elite offender can create a safe haven for their actions by virtue of their position. In 2014, The Pew Research Center released the findings of a global study in which it found that a median of $83 \%$ of people across 34 emerging and developing economies responded that crime in their countries was a major problem, and that $76 \%$ saw corrupt political leaders in the same way. Additionally, corruption was perceived to be highest in Africa, followed by Ukraine, Russia, and China. Respondents from Latin America, Africa, Asia and the Middle East saw crime and corruption as the greatest problems in their countries. [10]. Despite such findings of citizen recognition of the problem, Ross [8] noted that the proliferation of corruption also "hampers public 


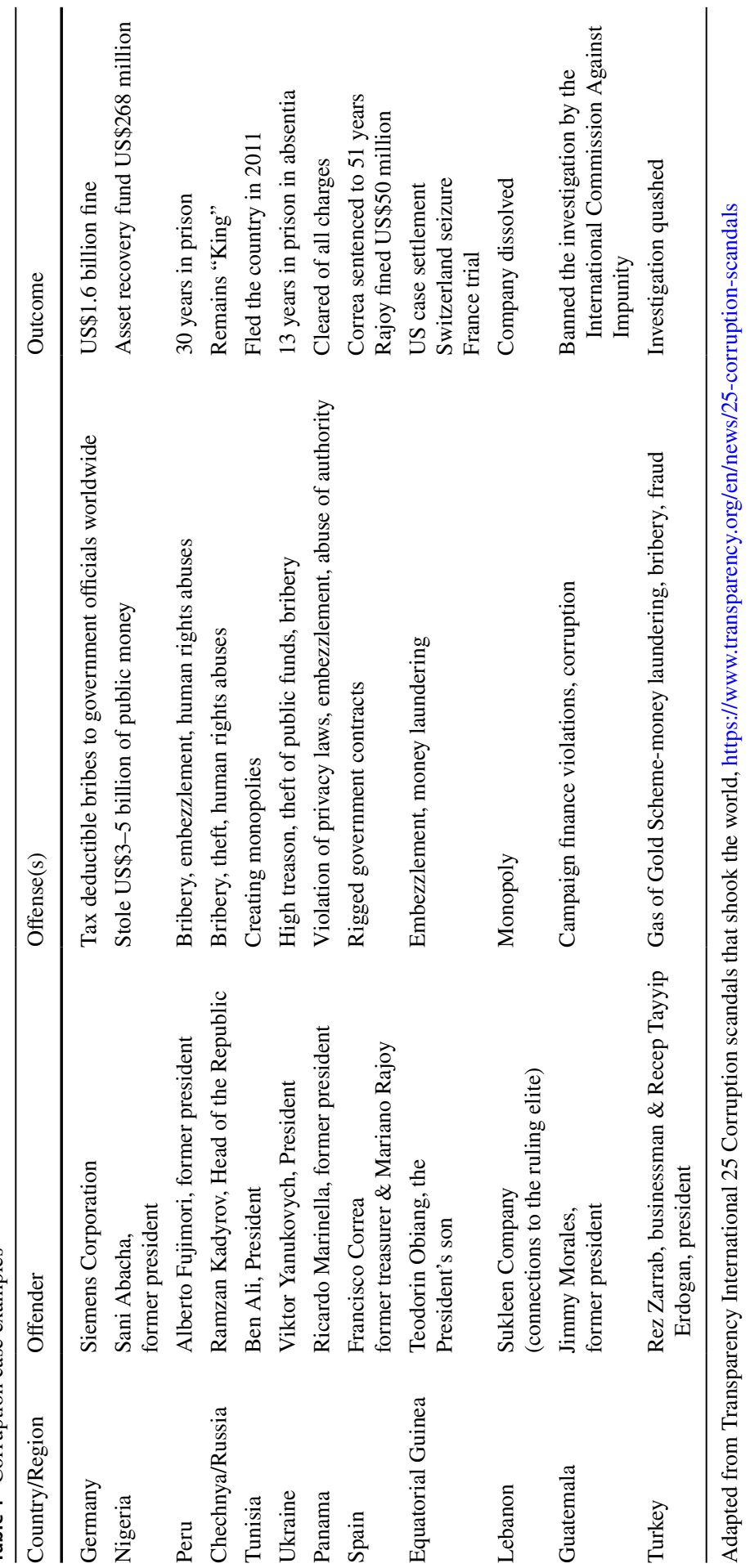


understanding" and results in "cynicism, skepticism, and complacency (p. 2)." Martinsson (this issue) cites a 2019 Pew Research Center survey finding that 81 percent of Americans distrust congress and 68 percent of the population in the European Union view corruption as a major problem.

Through detailed historical analysis, Børge Bakken and Jasmine Wang detail the growth of corruption in modern China. Their narrative of the influence of culturally embedded views identifies the changing forms of corruption in China and the connections between political elites and entrepreneurs. The authors adopt a critical perspective on white-collar crime in explaining how corruption and oppression is essential to exploitation that erodes public trust. The article places corruption in the contextual experiences of a single party autocracy that saw practices evolve that emphasized "decentralization without accountability," resulting in increased wrongdoing at local levels.

Joel Martinsson's article acknowledges that preventing corruption is problematic and that current approaches have created a false dichotomy. Martinsson emphasizes the need to look beyond the two popular frameworks-principle-agent and collective-action-in order to effectively prevent institutional corruption. He adopts a policy-centered approach toward systemic corruption that can address "honest graft" in established democracies. His portrayal of George Washington Plunkitt's case ironically mirrors current events in the United States, as well as global problems that systematically reproduce political crimes.

Efforts to research sanctions and prevention efforts directed at political crime are challenging, especially across local and global jurisdictions. Carlos Novella-García and Alexis Cloquell-Lozano's article addresses corruption in Spain. They employ a sophisticated analysis with a framework of Hermeneutic definitions of maxima and minima and social justice and offer prevention suggestions that stress the importance of public ethics as a mechanism for reducing corruption. They explore various theoretical approaches and provide a historical narrative for a case study of public corruption in Spain. When corruption is perceived as widespread, according to the authors, political and public ethics are needed to ensure that "the human condition is not easily corrupted by the act of wanting greater prestige, more power, and more money."

Despite progress in the study of political crime and corruption, they still rage on today throughout the world and result in major societal losses. Moreover, like whitecollar crime more generally, their social costs are physical as well as financial, or, as William Black has put it in challenging common business narratives, "corruption kills" [3]. Future research is warranted for both theory development, and prevention and control efforts.

Several major themes throughout the articles that follow are summarily captured by Ferrari who, a century ago, wrote:

This absolute contrast in the treatment of political criminals is due to a change of interpretation of their character and of their role from the point of view of the evolution of humanity. Whereas formerly the political criminal was treated as a public enemy, he is today considered as a friend of the public good, as a man of progress, desirous of bettering the political institutions of his country, 
having laudable intentions, hastening the onward march of humanity, his only fault being that he wishes to go too fast, and that he employs, in attempting to realize the progress which he desires, means irregular, illegal and violent (1920: 312).

Ferrari, despite the dearth of literature on white-collar crime at the time, further concluded that the "political criminal is reprehensible and ought to be punished in the interest of the established order, his criminality can- not be compared with that of the ordinary malefactor, with the murderer, the thief, etc."

We extend our appreciation and thanks to all the authors who contributed to this valuable and timely issue.

Mary Dodge and Henry N. Pontell.

\section{References}

1. Allen, H. E., Friday, P. C., Roebuck, J. B., \& Sagarin, E. (1981). Crime and punishment: An introduction to criminology (pp. 4-8). Free Press.

2. Barak, G. (1991). Crimes by the capitalist state: An introduction to state criminality. State University of New York Press.

3. Black, W. K. (2007). Corruption kills. In H. N. Pontell \& G. Geis (Eds.), International Handbook of White-Collar and Corporate Crime (pp. 439-455). Springer.

4. Ferrari, R. (1920). Political crime. Columbia Law Review, 20, 308.

5. Friedrichs, D. O. (2000). State crime or governmental crimes: Making sense of the conceptual confusion. In J. A. Ross (Ed.), Controlling state crime (pp. 53-80). Transaction Publishers.

6. Geis, G., \& Meier, R. F. (1977). White-collar crime: Offenses in business, politics, and the professions (rev). Free Press.

7. Hagan, F. E. (1997). Political crime: Ideology and criminality. Allyn and Bacon.

8. Ross, J. A. (2003). The dynamics of political crime. Sage Publications.

9. Ross, J. A. (2000). Controlling state crime (2nd ed.). Transaction Publishers.

10. Pew Research Center (2014). Crime and corruption top problems in emerging and developing countries. Retrieved from https://www.pewresearch.org/global/2014/11/06/crime-and-corruption-topproblems-in-emerging-and-developing-countries/2014/11/06/crime-and-corruption-top-problemsin-emerging-and-developing-countries/. Accessed $20 \mathrm{Feb} 2021$.

11. Sharkansky, I. (2000). A state action may be nasty but is not likely to be a crime. In J. A. Ross (Ed.), Controlling state crime (pp. 35-52). Transaction Publishers.

12. Shover, N., \& Wright, J. P. (Eds.). (2001). Crimes of privilege: Readings in white-collar crime. Oxford University Press.

13. The Guardian (2015). Retrieved from https://www.theguardian.com/world/2015/sep/23/putins-close st-ally-and-his-biggest-liability2015/sep/23/putins-closest-ally-and-his-biggest-liability. Accessed $20 \mathrm{Feb} 2021$.

14. Transparency International (2019). Retrieved from https://www.transparency.org/en/news/25-corru ption-scandals\#Siemens. Accessed 20 Feb 2021.

Publisher's Note Springer Nature remains neutral with regard to jurisdictional claims in published maps and institutional affiliations. 